\title{
Molecular characterization and bioinformatics analysis of Ncoa7B, a novel ovulation-associated and reproduction system-specific Ncoa7 isoform
}

\author{
Ketty Shkolnik ${ }^{1}$, Shifra Ben-Dor ${ }^{2}$, Dalia Galiani ${ }^{1}$, Ariel Hourvitz ${ }^{3}$ and Nava Dekel ${ }^{1}$ \\ Departments of ${ }^{1}$ Biological Regulation and ${ }^{2}$ Biological Services, Weizmann Institute of Science, PO Box 26, Rehovot \\ 76100, Israel and ${ }^{3}$ IVF Unit, Department of Obstetrics and Gynecology, Chaim Sheba Medical Centre, Tel-Hashomer \\ 52621, Israel \\ Correspondence should be addressed to N Dekel; Email: nava.dekel@weizmann.ac.il
}

K Shkolnik and S Ben-Dor contributed equally to this work

\begin{abstract}
In the present work, we employed bioinformatics search tools to select ovulation-associated cDNA clones with a preference for those representing putative novel genes. Detailed characterization of one of these transcripts, $6 \mathrm{C} 3$, by real-time PCR and RACE analyses led to identification of a novel ovulation-associated gene, designated Ncoa7B. This gene was found to exhibit a significant homology to the $N c o a 7$ gene that encodes a conserved tissue-specific nuclear receptor coactivator. Unlike Ncoa7, Ncoa7B possesses a unique and highly conserved exon at the $5^{\prime}$ end and encodes a protein with a unique $N$-terminal sequence. Extensive bioinformatics analysis has revealed that $N c o a 7 B$ has one identifiable domain, TLDc, which has recently been suggested to be involved in protection from oxidative DNA damage. An alignment of TLDc domain containing proteins was performed, and the closest relative identified was $O X R 1$, which also has a corresponding, highly related short isoform, with just a TLDc domain. Moreover, Ncoa7B expression, as seen to date, seems to be restricted to mammals, while other TLDc family members have no such restriction. Multiple tissue analysis revealed that unlike Ncoa7, which was abundant in a variety of tissues with the highest expression in the brain, Ncoa7B mRNA expression is restricted to the reproductive system organs, particularly the uterus and the ovary. The ovarian expression of $N \operatorname{coa} B \mathrm{~B}$ was stimulated by human chorionic gonadotropin. Additionally, using real-time PCR, we demonstrated the involvement of multiple signaling pathways for $\mathrm{Ncoa}$ B B expression on preovulatory follicles.

Reproduction (2008) 135 321-333
\end{abstract}

\section{Introduction}

The release of the female germ cell from the ovary, known as ovulation, is a key event in mammalian reproduction. To prepare for ovulation, some selected ovarian follicles mature to the preovulatory stage, during which the combined actions of follicle-stimulating hormone, estradiol, and various growth factors take place (Richards 1979, Robker \& Richards 1998, Sharma et al. 1999). Consequently, theca cells begin to synthesize increasing amounts of androgens and granulosa cells express luteinizing hormone $(\mathrm{LH})$ receptors, acquiring the ability to respond to $\mathrm{LH}$ and to produce estrogens (reviewed in Eppig 1991, Richards 1994, Richards et al. 2002a).

The sequence of temporal events that occur during ovulation is initiated by the surge of $\mathrm{LH}$, which induces transcription of specific genes that are transiently expressed prior to follicular rupture. During the past five decades, there has been an increasing effort to identify and unveil the function of the molecules that bring about the rupture of mature ovarian follicles in response to the ovulation-stimulating LH surge. The crucial importance of some such ovulatory genes (genes with increased expression in the interval of $\sim 12 \mathrm{~h}$ after the $\mathrm{LH}$ surge) was established by the studies proceeded on a single-case basis. More recently, the application of genomic era technologies such as differential display (DD)-RT-PCR and cDNA array combined with increased access to genomic information (Hsu \& Hsueh 2000) and tissue-specific databases (Leo et al. 2000) has led to new insights into novel genes that control ovulation.

Genes known to be induced by $\mathrm{LH}$ during the ovulatory process include the progesterone receptor $(P R$; Park \& Mayo 1991), cyclooxygenase-2 (COX2; Sirois \& Richards 1992), CAAT-enhancer-binding protein $\beta$ (CEBPB; Sirois \& Richards 1993), early growth regulatory factor (Egr1; Espey et al. 2000), pituitary adenylyl cyclase-activating peptide (PACAP; Park et al. 2000), amphiregulin (Areg; Park et al. 2004), receptor-interacting protein 140 (RIP140; Tullet et al. 2005), hyaluronan synthase-2 (HAS2), tumor necrosis-stimulated gene-6 (TSG6; Richards 2005), 
endothelin-2 (EDN2; Ko et al. 2006), estrogen sulfotransferase (EST; Gershon etal. 2007), and other genes identified by microarray analysis (Leo et al. 2001, Jo et al. 2004), DD-RT-PCR (Espey \& Richards 2002), and suppression subtractive hybridization (SSH; Hourvitz et al. 2006, Gershon et al. 2007). Some of the above-mentioned genes have been demonstrated as essential players in the ovulatory cascade, whereas the role of other genes, the expression of which is up-regulated following the $\mathrm{LH}$ surge, awaits further investigation. Moreover, the identification of new crucial players in this highly complex preovulatory cascade is of major significance.

In our previous study, the SSH approach (Diatchenko et al. 1996) was applied in order to systematically isolate genes with an ovulation-associated pattern of expression (Hourvitz et al. 2006). In the present work, we employed bioinformatics search tools to select cDNA clones with a preference for those representing putative novel genes. The detailed characterization of one of these transcripts, $6 \mathrm{C} 3$, leads to the identification of a novel ovulationassociated gene, designated Ncoa7B (GenBank accession number: EF602028). Ncoa7B, an isoform of the Ncoa7 gene (nuclear receptor coactivator 7 , also known as estrogen receptor activator protein, ERAP140), seems to be evolutionarily restricted to mammals and possesses a highly conserved TLDc domain. Unlike Ncoa7, which is abundant in a variety of tissues, $N \operatorname{coa} 7 B$ mRNA expression is restricted to the organs of the reproductive system. The ovarian expression of this gene is stimulated by human chorionic gonadotropin (hCG)/ $\mathrm{LH}$ and mediated by protein kinase $\mathrm{A}$ (PKA) and partially by protein kinase $C$ (PKC) signaling pathways. An involvement of p38 kinase has also been demonstrated.

\section{Results \\ Prioritization of the SSH library-deduced novel clones employing advanced bioinformatics search tools}

We have previously reported the isolation of 252 genes, via the differential screening technique $\mathrm{SSH}$, that are selectively or exclusively expressed during ovulation in the mouse ovary (Hourvitz et al. 2006). As part of this work, a preliminary basic local alignment search tool (BLAST)-based screen was performed to identify putatively novel genes, which resulted in a list of 85 clones.

In the present study, we employed two database similarity searches, BLASTn analysis in combination with BLAST-like alignment tool (BLAT) to select cDNA clones with a preference for those representing putative novel genes. The cDNAs were designated as novel if they fulfilled one of two conditions: either lack of homology to sequence entries deposited in publicly accessible, non-redundant nucleotide databases or if they matched a full-length or partial sequence whose function has not yet been determined in either mouse or human.
Of the 85 preliminary clones, 24 novel cDNAs were selected for further validation of their ovulation-associated expression pattern. This choice was guided by the following criteria: additional mRNAs/expressed sequence tags (ESTs) that match the clones (indicating reliability of the sequence), protein prediction, putative protein domains (possible relation to ovulation), literature (known isoforms etc), evolutionary conservation of the sequence, and tissue expression pattern of the matching mRNAs/ESTs.

\section{Expression of the $6 C 3$ clone, potentially representing a novel ovarian gene, is transiently induced in an hCG-dependent manner}

To validate the hCG-dependent expression pattern of the selected 24 cDNA clones, we applied the relative realtime PCR method. Ovarian RNA from pregnant mare's serum gonadotropin (PMSG)-primed mice killed at 0, 2, $4,6,8,12,24$, and $48 \mathrm{~h}$ following the administration of hCG was used for cDNA synthesis. Highly specific primers were designed for each candidate clone (using Beacon Designer software, Bio-Rad) and the expression pattern of these cDNAs in mouse ovaries during the preovulatory period was examined. Out of the 24 candidate clones, 6 exhibited an hCG-dependent pattern of expression. As determined by real-time PCR analysis, the novel 6C3 transcript demonstrated the highest phasedependent increase of expression among the validated clones, with a 35 -fold elevation at $4 \mathrm{~h}$ after hCG administration (Fig. 1). The increased level of expression was sustained up to the time of ovulation (about $12 \mathrm{~h}$ after hCG administration) and, subsequently, dropped to near-baseline levels upon the transition into corpora lutea (24 and $48 \mathrm{~h}$ after hCG injection). Moreover, initial characterization of the $6 \mathrm{C} 3$ clone by BLAT revealed that it is located in the same genomic locus as the Ncoa7

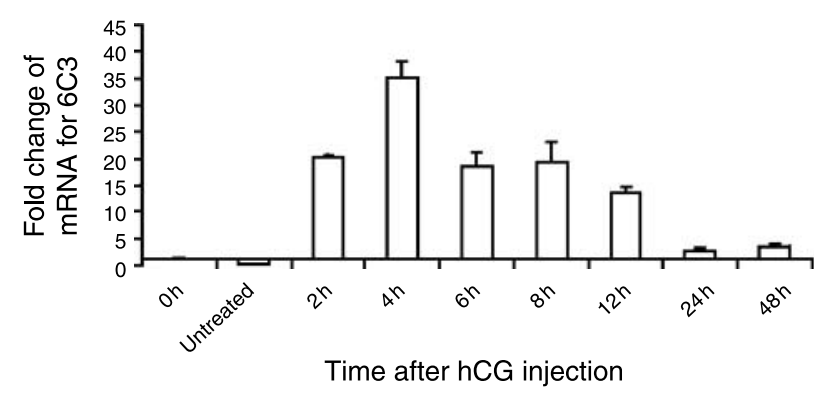

Figure 1 hCG-induced expression pattern of the $6 \mathrm{C} 3$ clone by real-time PCR. Ovarian RNA was isolated from untreated, control $(0 \mathrm{~h}$,

PMSG-primed, no hCG), and PMSG-primed mice at the designated time points after hCG administration (2, 4, 6, 8, 12, 24, and $48 \mathrm{~h})$. The mRNA expression values are relative to the control $(0 \mathrm{~h})$ sample. The values were normalized to the mRNA levels of the reference gene, $B 2 \mathrm{~m}$. Representative experiment that reflects a common trend of a transient hCG-induced elevation of mRNA in at least three independent in vivo experiments is shown. Error bars represent the standard error of triplicate samples. 
gene with a partial overlap to two exons of Ncoa7 (Fig. 3A); however, the $5^{\prime}$ end of 6C3 is unique, and not present in full-length Ncoa7.

\section{Cloning and sequencing of the novel ovulation- associated Ncoa7B gene, an isoform of the Ncoa7 gene}

Since SSH yields only partial cDNA fragments (304 bp for clone 6C3), RACE methodology was used to accomplish the identification of the complete $5^{\prime}$ and $3^{\prime}$ sequences. The $5^{\prime}$ and $3^{\prime}$ RACE PCR products, $87 \mathrm{bp}$ and
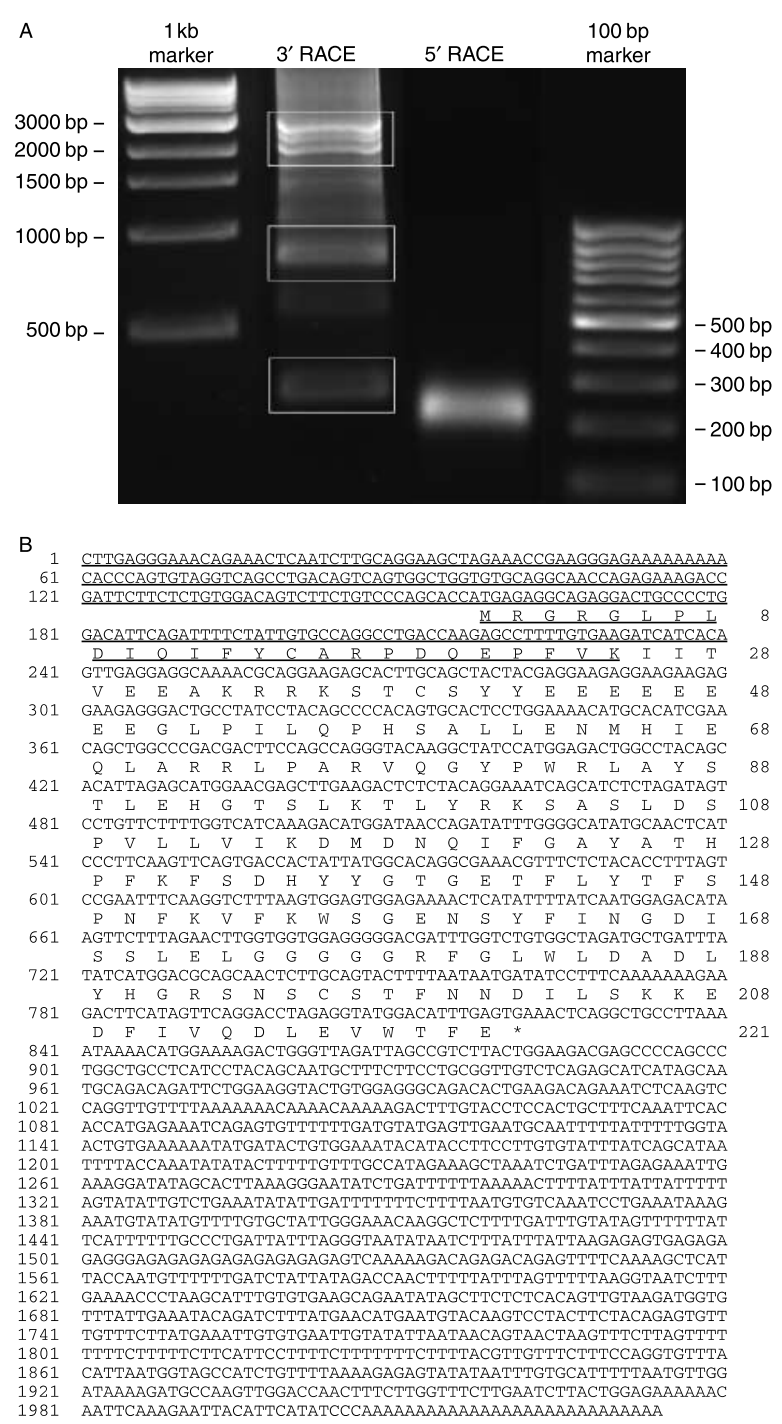

Figure 2 The full-length cDNA sequence of the $6 \mathrm{C} 3$ clone, as determined by RACE, corresponds to a novel short isoform of Ncoa7, designated Ncoa7B. (A) The PCR products isolated from the $5^{\prime}$ and $3^{\prime}$ RACE reactions. Marked PCR bands from the $3^{\prime}$ RACE reaction were isolated and its sequence was analyzed. PCR products from the top rectangle represent the full-length $3^{\prime}$ sequence of $N$ coa $7 B$, while other bands are partial sequences. (B) Nucleotide and deduced amino acid sequence of $N$ coa $7 B$. Marked nucleotides and amino acids indicate the unique sequence of the novel $N$ coa $7 B$ isoform.
1934 bp respectively (Fig. 2A) were isolated, cloned, and several randomly isolated clones were sequenced. The full-length cDNA sequence (GenBank accession number: EF602028, 2034 bp) was subjected to BLAT analysis and found to possess significant homology to Ncoa7 at the $3^{\prime}$ end, whereas the $5^{\prime}$ most exon is unique to this isoform, designated $N \operatorname{coa} 7 B$ (Fig. 2B). From the fulllength $N$ соа7B cDNA sequence, a single open reading frame (ORF) was identified that encodes a protein of 221 amino acids (Fig. 2B). NCOA7B has 25 unique amino acids at its $\mathrm{N}$-terminus (Figs $2 \mathrm{~B}$ and 3 ). The BLAT analysis showed several other CDNAs in the database that also encode for this short isoform.

NCOA7, also known as ERAP140, is a large protein with 943 amino acids. It was shown to bind and respond to estrogen receptor $\alpha(\mathrm{ER} \alpha)$ and other nuclear receptors, acting as a transcriptional activator (Shao et al. 2002). However, the ER $\alpha$-interacting domain of ERAP140 is in the central portion of the protein, which is absent in the novel isoform, NCOA7B. Domain analysis (Fig. 3B) showed two additional domains in the $\mathrm{N}$-terminal region of the protein, which is missing in NCOA7B, a LysM domain and a Gram domain, both of unknown function. The only domain that is common to both Ncoa7 and Ncoa7B is the TLDc, which consists the major portion of Ncoa7B (59-221 aa). This domain is of undetermined function, though a recent paper suggests its involvement in protection from oxidative damage (Durand et al. 2007).

\section{Ncoa7B is a member of a large and widely distributed gene family}

BLASTp analysis was performed to identify related protein sequences to NCOA7B in other organisms and other protein families. The results yielded both full-length NCOA7 and NCOA7B in several species, and four other TLDc-containing protein families: OXR1, C20ORF118, KIAA1609, and TBC1D24. The BLAST hits were cleaned to remove fragments, redundancies, and predicted proteins. One of the related protein families, OXR1, also has a short form with a novel exon equivalent to NCOA7B, called C7C (Fischer et al. 2001). We performed two alignments, one of the short isoform proteins, NCOA7B and C7C (Fig. 4), and the other of the TLDC domain of all of the proteins found (Fig. 5A). A phylogenetic tree was built based on the latter alignment (Fig. 5B).

OXR1 is the closest relative of NCOA7. Their genomic structures are very similar, and NCOA7 seems to be a relatively recent duplication of OXR1. Both proteins have LysM, Gram, and TLDc domains, though only Ncoa7 has an ERabd (Fig. 6). In addition, OXR1 is the only other family member to have both short and long isoforms. The OXR1 short isoform (C7C) has very high similarity to NCOA7B especially in the TLDc domain, and to a lesser, but still significant extent in the $\mathrm{N}$-terminal regions of the proteins (Fig. 4). The long isoforms of both NCOA7 and 
A

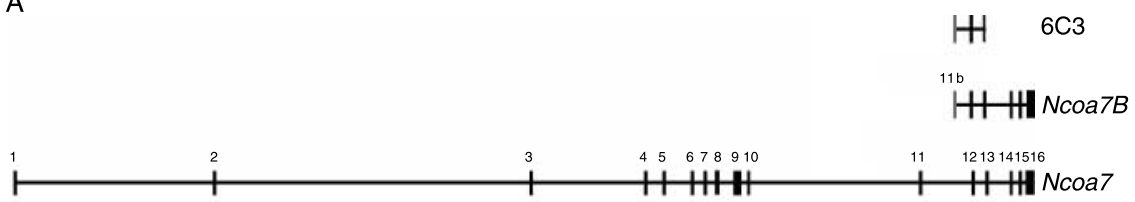

Figure 3 (A) Genomic structure of $6 \mathrm{C} 3$, Ncoa7B, and full-length Ncoa7. The 6C3 is the $\mathrm{SSH}$ fragment originally isolated and spans three exons. Ncoa7B comprises six exons. The first exon is unique to this isoform, B

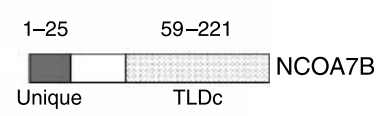
the others are shared with Ncoa7; this creates a unique $\mathrm{N}$-terminus in the protein. (B) Protein scheme with domains of NCOA7B and full-length NCOA7. NCOA7B and

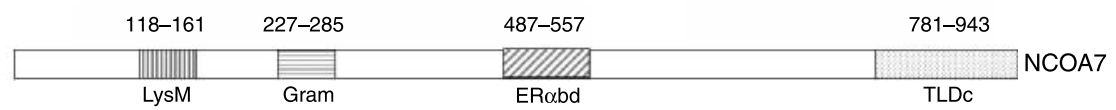
NCOA7 share one TLDc domain, which is defined by sequence similarity.

OXR1 are found in a variety of vertebrates, ranging from man to chicken or frog respectively (Fig. 5A). However, to date, NCOA7B has only been found in mammals, whereas $\mathrm{C} 7 \mathrm{C}$ is also found in frogs. OXR1 is the only relative of NCOA7/NCOA7B with a known function, that of protection from oxidative damage.

The next closest relative is C20ORF118. C20ORF118 exists only in a short form and has a unique $\mathrm{N}$-terminal portion followed by the TLDc domain. In contrast to OXR1, the unique portion of C20ORF118 is noticeably different from the unique portion of NCOA7B. This gene has no known function, and to date is found only in mammals. KIAA1609 and TBC1D24 are more distant relatives, with varying genomic structure and a wider evolutionary spread (Fig. 5B). Their function is also unknown. TBC1D24 has an additional domain, the TBC domain, also of unknown function (Fig. 6).

The TLDc domain is highly conserved along its whole length (Fig. 5A), with the exception of family-specific extensions. The TBC1D24 family has two extensions, one major and one minor, while KIAA1609 adds one minor extension. Each subfamily is strongly related, while the interfamily relationship is slightly weaker. Ignoring the extensions, the length of the domain is $\sim 165$ amino acids, of them, 83 are conserved in more than $50 \%$ of the sequences.

\section{Tissue distribution of the novel Ncoa7B gene when compared with Ncoa7}

To establish the expression profiles of $N$ coa $7 B$ and Ncoa7 in diverse mouse tissues, RNA was extracted and subjected to semi-quantitative RT-PCR analysis using highly specific primers for each gene. To note, the majority of the tissues were extracted from both nontreated and PMSG/hCG-treated female mice. Examination of a panel of 16 mouse tissues demonstrated that Ncoa7B mRNA was highly abundant at the preovulatory mouse ovary ( $5 \mathrm{~h}$ after hCG injection to PMSG-primed mice) as well as in the uterus (Fig. 7). Its expression was not detected in brain, eye, liver, and testis and was detected at very low levels in other tested tissues. Consistent with a previous report (Shao et al. 2002), expression of Ncoa7 was most abundant in the brain, while high expression was also observed in the lung, eye, spleen, kidney, and hCG-treated ovary and testis. To note, real-time PCR analysis of ovarian tissue revealed that the mRNA level of Ncoa7 was elevated to a much lesser extent (data not shown) when compared with the
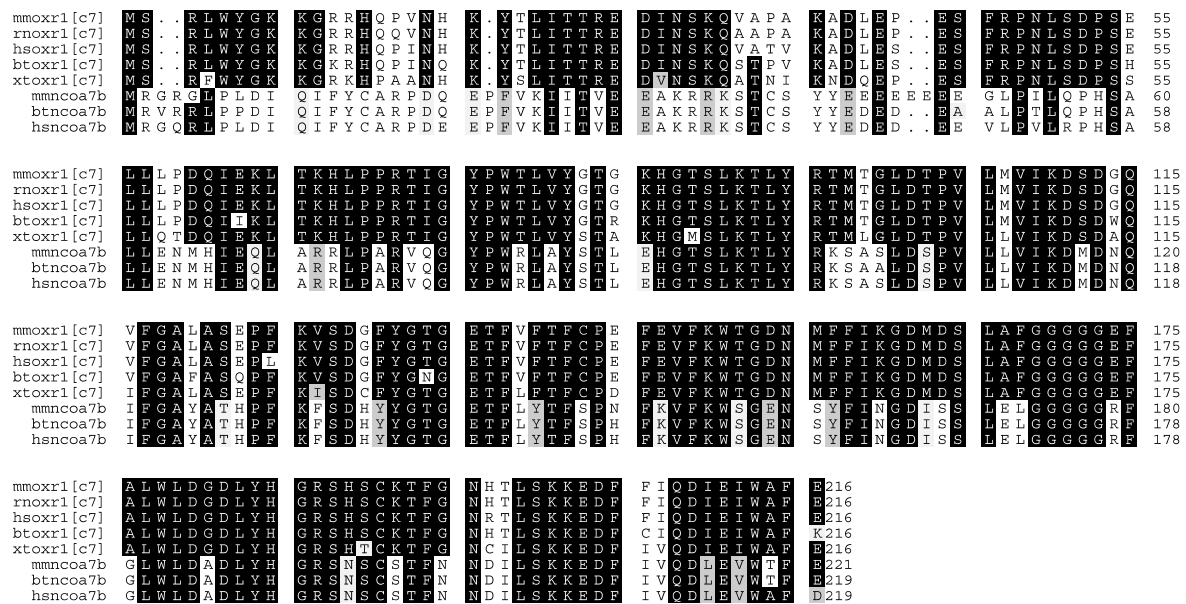

Figure 4 Multiple alignment of the short isoforms of NCOA7 (NCOA7B) and OXR1 (C7). Multiple alignment of the full-length $\mathrm{NCOA} 7 \mathrm{~B}$ and $\mathrm{C} 7$, including the unique $\mathrm{N}$-terminal region and the TLDc domain. The TLDc domains are highly conserved between the two protein families, and the unique regions to a lesser extent. Both the unique regions and the TLDc domain are highly conserved between the two protein families. 
Ncoa7B isoform that showed a dramatic increase in the expression following hCG administration.

Overall, the contrast in the tissue expression patterns of the two isoforms in combination with the difference in the sequence level may imply a distinct functional specialization of each isoform in the particular tissues.

\section{Hormonal regulation of Ncoa7B transcript expression in cultured ovarian follicles, granulosa cells, and cumulus-oocyte complexes (COCs)}

To determine whether the transient increase in the levels of Ncoa7B mRNA after hCG administration in vivo can be mimicked in vitro and whether the induction of this gene is directly mediated by the action of $\mathrm{LH}$, large antral ovarian follicles isolated from immature PMSG-primed mice were cultured in the absence $\left(0_{1}\right.$ and $O_{2}$ h samples) or presence of $\mathrm{LH}$ for the designated incubation times. As shown in Fig. 8A, LH treatment induced a dramatic, transient increase in the levels of Ncoa7B mRNA; the expression levels were the highest between 3 and $9 \mathrm{~h}$ of culture and then began to decline by $12 \mathrm{~h}$. This transient expression pattern resembles that of Ncoa7B mRNA in ovaries of PMSG/hCG-treated mice in vivo (Fig. 1).

We further showed by RT-PCR analysis that the up-regulation of $N$ coa7B mRNA occurred in both the granulosa cells and the COCs of the preovulatory ovarian follicles from PMSG/hCG-treated mice (Fig. 8B). It could be clearly seen that upon hCG administration, there is a substantial increase in the $N$ coa7B expression when compared with the control sample $(0 \mathrm{~h})$.

\section{Intracellular signaling involved in the induction of Ncoa7B mRNA expression in cultured ovarian follicles in vitro}

It was previously shown that $\mathrm{LH}$ activates both PKA and PKC signaling pathways to induce the expression of preovulatory genes, such as prostaglandin-endoperoxide synthase 2 (Ptgs2) and PR in preovulatory rat follicles (Natraj \& Richards 1993, Morris \& Richards 1995).

To differentiate the activation of PKA from that of PKC signaling, we cultured large antral ovarian follicles from PMSG-primed mice in the absence or presence of either forskolin or tetradecanoyl phorbol acetate (TPA). Forskolin is an activator of adenylate cyclase that catalyzes the formation of CAMP. PKA is the downstream effector of this pathway. TPA is a potent synthetic activator of PKC. The ovarian follicles were incubated for $5 \mathrm{~h}$ with either of the activators. This time was required for maximal $N$ coa $7 B$ mRNA expression in the preovulatory ovaries in vivo and in the ovarian follicles in vitro. As seen in Fig. 9A, LH stimulated Ncoa7B mRNA expression in cultured ovarian follicles $(P<0.05)$. Treatment with forskolin stimulated a similar level of gene expression, whereas TPA stimulated the Ncoa7B expression to a lesser extent (Fig. 9A). The effect of $\mathrm{LH}$ on
Ncoa7B mRNA expression was totally inhibited by specific inhibitors of PKA (H89, $25 \mu \mathrm{M})$, MAPK kinase (MEK, UO126 $10 \mu \mathrm{M}$ ), and p38 kinase (SB202190, $20 \mu \mathrm{M})$, but to a lesser degree by the inhibitor of PKC (GF109203, $10 \mu \mathrm{M}$; Fig. 9A and B). We used doses of these inhibitors that have been shown previously to block the activation of their respective kinases in mouse follicular cultures (data not shown).

\section{Discussion}

In the present work, we employed molecular studies in combination with extensive bioinformatics tools to identify and characterize a novel ovulation-associated and reproductive organ-restricted gene, Ncoa7B. This gene was found to possess significant homology to the Ncoa7 gene (ERAP140) and to include a unique and highly conserved exon at the $5^{\prime}$ end, which encodes for a protein with a unique N-terminal sequence. NCOA7 (ERAP140) represents a distinct class of nuclear receptor coactivators that mediate receptor signaling via the interaction of an $E R \alpha-$ binding domain (ERabd) with a variety of nuclear receptors, such as ER $\alpha, E R \beta$, and PPAR $\alpha$. It was also shown that ERAP140 can enhance the transcriptional activities of nuclear receptors with which it interacts (Shao et al. 2002). The ERabd is located in the central portion of the ERAP140 protein, which is not present in NCOA7B, suggesting an absence of transcription coactivity function for this novel isoform. As the majority of the known domains of NCOA7 are absent in $\mathrm{NCOA} 7 \mathrm{~B}$, the functions of the two proteins are most probably distinct. The one domain that is common to both NCOA7 and NCOA7B and consists of the major portion of NCOA7B (59-221 aa) is the TLDc domain.

The TLDc domain is of undetermined function, though a recent paper suggests its involvement in protection from oxidative damage (Durand et al. 2007). Moreover, previous studies of the yeast Oxr1 gene, which also contains a TLDc domain, indicate that it functions to protect cells from oxidative damage (Volkert et al. 2000, Elliott \& Volkert 2004). The oxidative DNA damage occurs when reactive oxygen species (ROS), formed as byproducts of aerobic organisms' metabolism, reacts with DNA (Ramotar et al. 1991). The damage produced by ROS has been implicated as a contributing cause of cancer, neurodegenerative diseases, and aging (Loft \& Poulsen 1996, Croteau \& Bohr 1997, Marnett 2000). Since the ovulatory process has biophysical and biochemical features that are characteristic of acute inflammatory reactions (Espey 1980, 1994), ROS plays a physiological role during ovulation. The source of ROS is in inflammatory cells, such as macrophages and neutrophils, which are present in the ovary during ovulation (Nakamura et al. 1987, Adashi 1990, Brannstrom et al. 1993) and produce a great amount of free radicals. Moreover, reactive oxidants generated during follicular rupture damage the DNA of ovarian surface epithelial cells located within a limited diffusion radius, and it is conceivable that clonal expansion of these cells could 

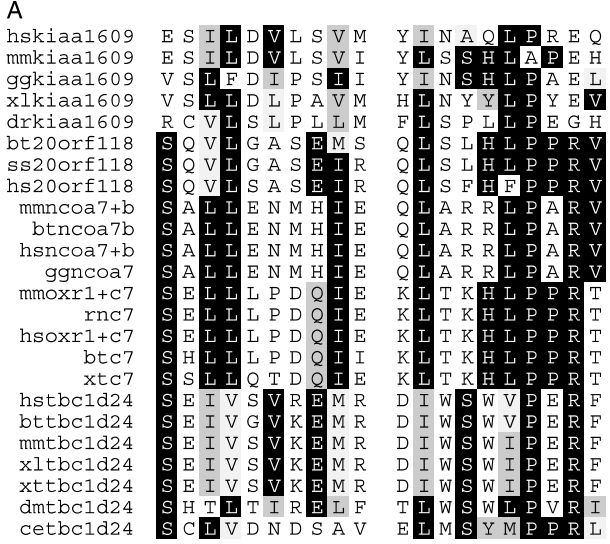

hskiaa1609 mmkiaal609 ggkiaal609 xlkiaal609 bt20orf118 bt20orf118 mmicoa $7+b$ btncoa7b sncoa $7+b$ $\underset{\operatorname{mgncoa} 7}{\operatorname{moxr} 1+\mathrm{C} 7}$ $\mathrm{rnc7}$
$\mathrm{hsox} 1+\mathrm{C} 7$ btc7 xtc7
hstbc1d24 $\begin{aligned} \text { xtc7 } & \text { A Q I F G A LA } \\ \text { hstbc1d24 } & \text { KE V C G A Y L } \\ \text { bttbc1d24 } & \text { KE V C G A Y L } \\ \text { mmtbcld24 } & \text { K E V C A }\end{aligned}$ mmtbcld 24
$\mathrm{xltbc} 1 \mathrm{~d} 24$ $x l t b c 1 d 24$
$x t t b c 1 d 24$ dmtbc1d24
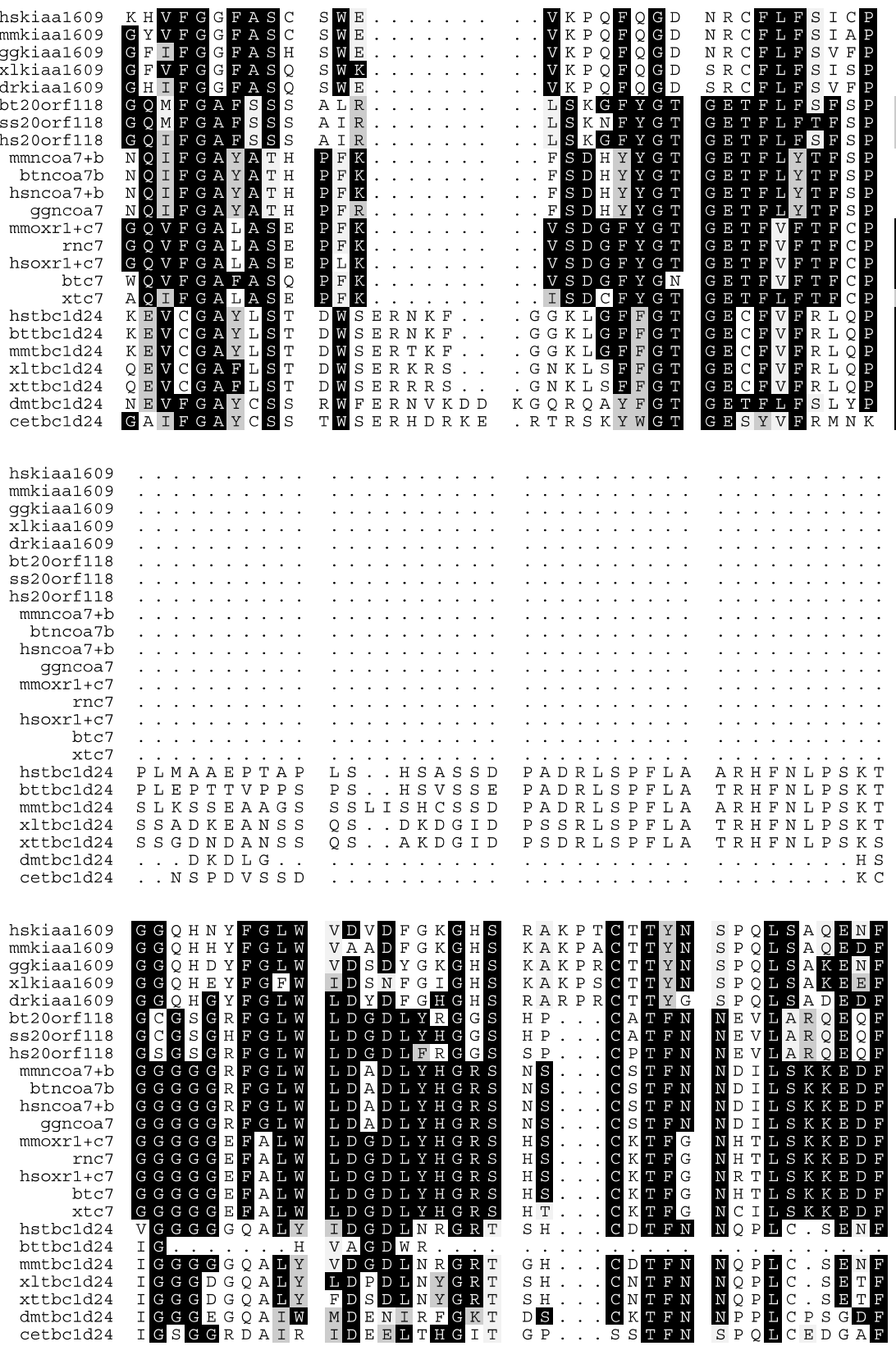

Figure 5 (legend continued)
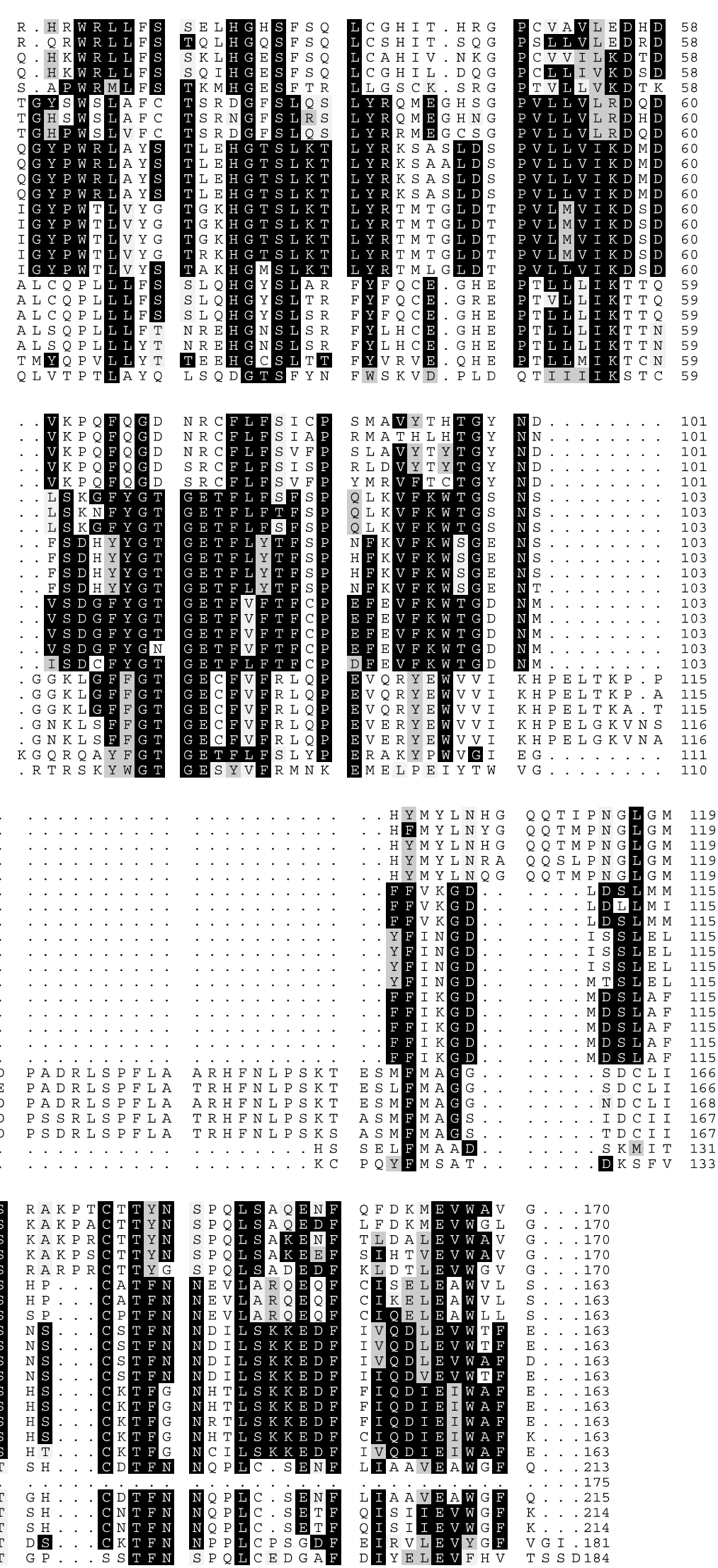


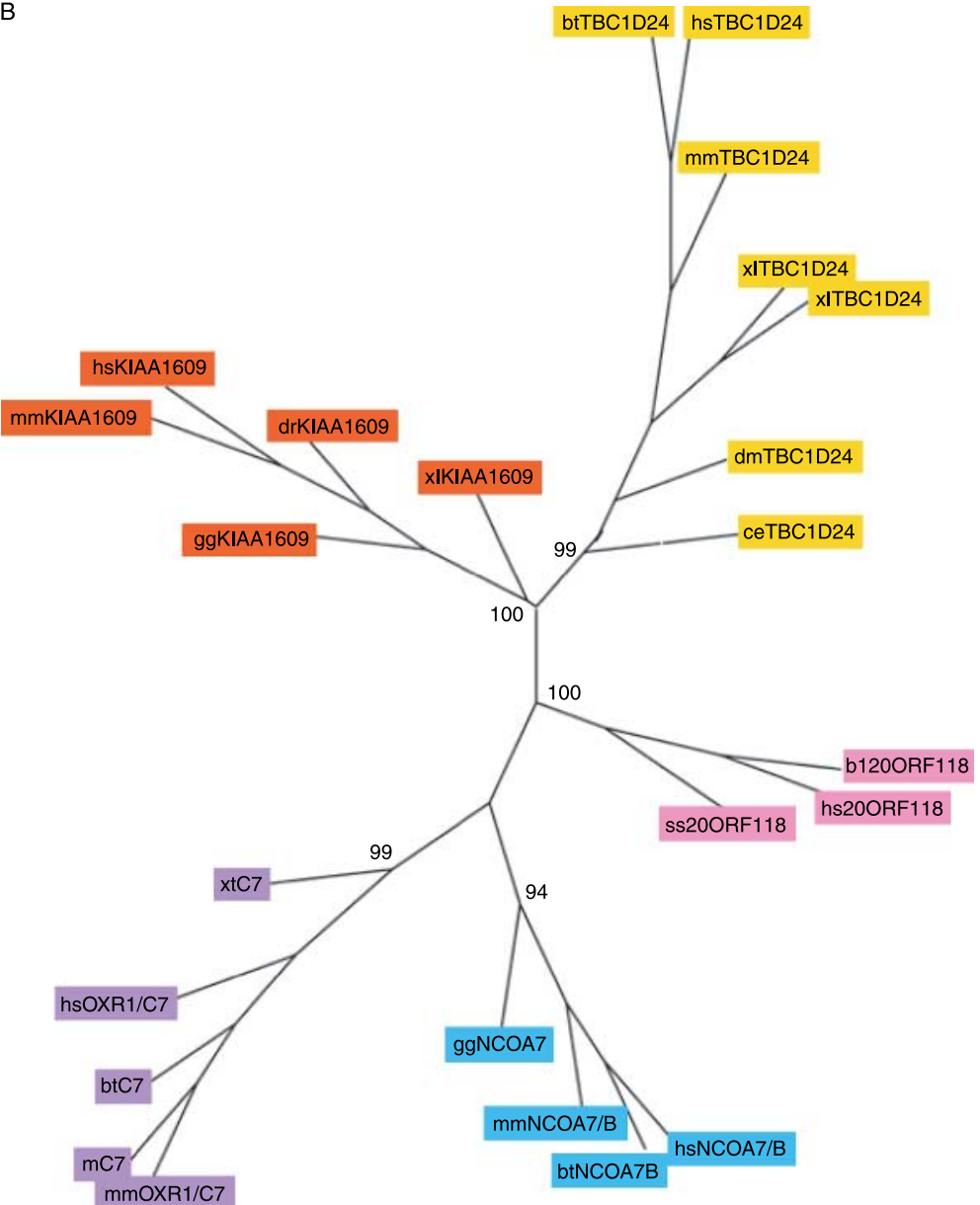

Figure 5 (A) Multiple alignment of the TLDc domain. Five families of proteins containing the domain were aligned using ClustalW, and visualized using Prettybox. All the sequences chosen are based on mRNA and are not predicted from genome sequence. The five families are: NCOA7, and its short isoform, NCOA7B; OXR1, and its short isoform, C7; C20ORF118; KIAA1609; and TBC1D24. When both the long and short forms exist for the same species, the domain is shown only once. Species: hs, Homo sapiens; mm, Mus musculus; gg, Gallus gallus; xl, Xenopus laevis; dr, Danio rerio; bt, Bos taurus; ss, Sus scrofa; rn, Rattus norvegicus; xt, Xenopus tropicalis; dm, Drosophila melanogaster; ce, Caenorhabditis elegans. (B) Phylogenetic tree of TLDc domain. The multiple alignment was used as the basis for a tree built with the Phylip package (Proml, maximum likelihood). Numbers at branch points represent bootstrap values out of 100 datasets. The five families all have significant branch points, though it is clear that those with short forms (NCOA7 and OXR1) are the most closely related, and next is C20ORF118, which has only a short form.

be an initiating factor of ovarian cancer (reviewed in Murdoch 2005). Considering the above-mentioned risk caused by ROS, we hypothesize that NCOA7B may play a specific role in ovarian tissue protection against the oxidative stress generated during ovulation.

The TLDc domain is highly conserved through evolution, as evidenced by proteins containing the domain from yeast to man (Volkert et al. 2000; Supplementary Figure 1, which can be viewed online at www.reproduction-online.org/supplemental). The fact that the domain is so conserved, even among protein families that are different overall (Fig. 6), points to its essential function. In fact, when we extend the tree in Fig. 5B to include more distantly related sequences, including yeast OXR1, several plant sequences, and more drosophila and Caenorhabditis elegans sequences, the mammalian Oxr1 family and the yeast Oxr1 proteins are on opposite ends of the tree (Supplementary Figure 1). This observation raises two important questions: (1) which of the five mammalian TLDc containing proteins is the actual yeast OXR1 ortholog and (2) is the function of the domain protection from oxidation (through whatever unknown mechanism), no matter which protein it is in? Importantly, Ncoa7B expression, as seen to date, seems to be restricted to mammals, while the majority of other TLDc family members, including full-length Ncoa7, have no such restriction. From the alignment of TLDc domain containing proteins, the closest relative of NCOA7 is shown to be OXR1, which also has a corresponding, highly related short variant, C7C (Fischer et al. 2001). OXR1 has been shown to be localized to the mitochondrion (Elliott \& Volkert 2004), while NCOA7 is localized to the nucleus (Durand et al. 2007). Of the other family members, KIAA1609 and 


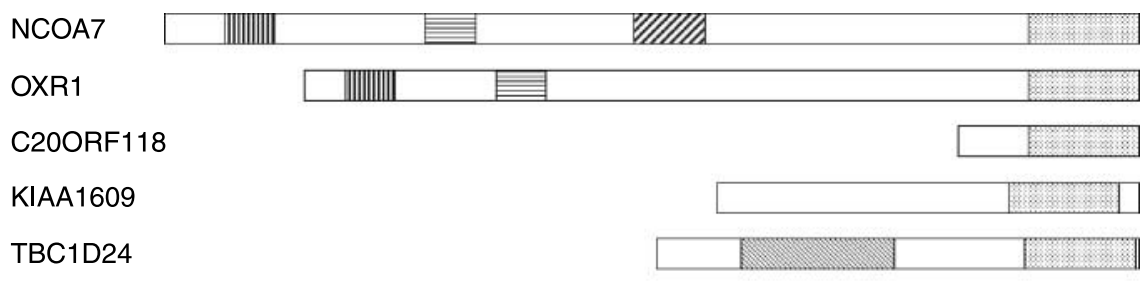

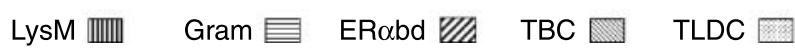

Figure 6 Domain architecture of the five mammalian TLDc containing proteins. The proteins were all taken from mouse (with the exception of C20ORF118, which has yet to be isolated in mouse, and was taken from human), and Interpro domain analysis was performed. The domains found are LysM (IPR002482), Gram (IPR004182), TLDc (IPR006571), and TBC (IPR000195). The ERabd is also shown, though its location was taken from Nakamura et al. (1987), and not InterPro.
TBC1D24 do not seem to have short forms and differ within the TLDc domain. C20ORF118, on the other hand, exists only in a short form. It seems likely that the different functions of the various short isoforms will depend on factors like tissue distribution and subcellular localization about which complete information is lacking for all of these genes. For NCOA7B, it remains to be seen whether the short form is targeted to the nucleus as the full-length NCOA7 is. As suggested in a previous study (Shao et al. 2002) and confirmed in our work, the mouse Ncoa7 gene is expressed in a variety of tissues with the highest abundance in the brain, specifically in the brain neurons. However, the expression of the $N$ coa $7 B$ isoform was restricted to the reproductive system organs, the ovary and the uterus, indicating that $N$ coa $7 B$ may have specific functions in this system. Moreover, that Ncoa7B mRNA was mostly abundant in ovarian tissue, particularly following hCG treatment, implies that this novel isoform plays a specific role in ovulation. By performing multiple tissue array analysis of the Ncoa7 and Ncoa7B isoforms, we have demonstrated that in addition to the significant differences at the sequence level between these genes, there is a significant variability in the tissue expression. These findings may suggest distinctive functions in completely different tissues for these isoforms.
Using large antral follicle cultures, we demonstrated that $\mathrm{LH} / \mathrm{hCG}$ induces a transient expression of $N$ coa $7 B$ mRNA, which was also evident in the granulosa cells and COCs cultures. These expression patterns in vitro are strikingly similar to those seen in vivo, demonstrating that the increase of $N$ соа $7 B$ mRNA expression results from the direct action of $\mathrm{LH}$ on its cognate receptor in preovulatory ovarian follicles. Importantly, the cultured ovarian follicles could therefore be employed as an experimental model to investigate the $\mathrm{LH}$-induced signaling pathways that regulate the $N$ coa $B \mathrm{~B}$ mRA expression.

It is well known that the binding of $\mathrm{LH}$ to its receptor activates adenylate cyclase, which leads in turn to cAMP-mediated responses, predominantly through the PKA-signaling pathway (Richards et al. 2002b). Additionally, other kinase-dependent signaling pathways, including PKC, have been implicated as the mediators of the LH-induced preovulatory signaling cascade (Morris \& Richards 1995, Carvalho et al. 2003, Hsieh \& Conti 2005). A study performed by Salvador et al. (2002) has demonstrated that the stimulation of the LH receptor by hCG in rat preovulatory granulosa cells in vitro leads to the activation of two independent pathways. One is PKA-dependent and signals through the activation of MEK and p42/44
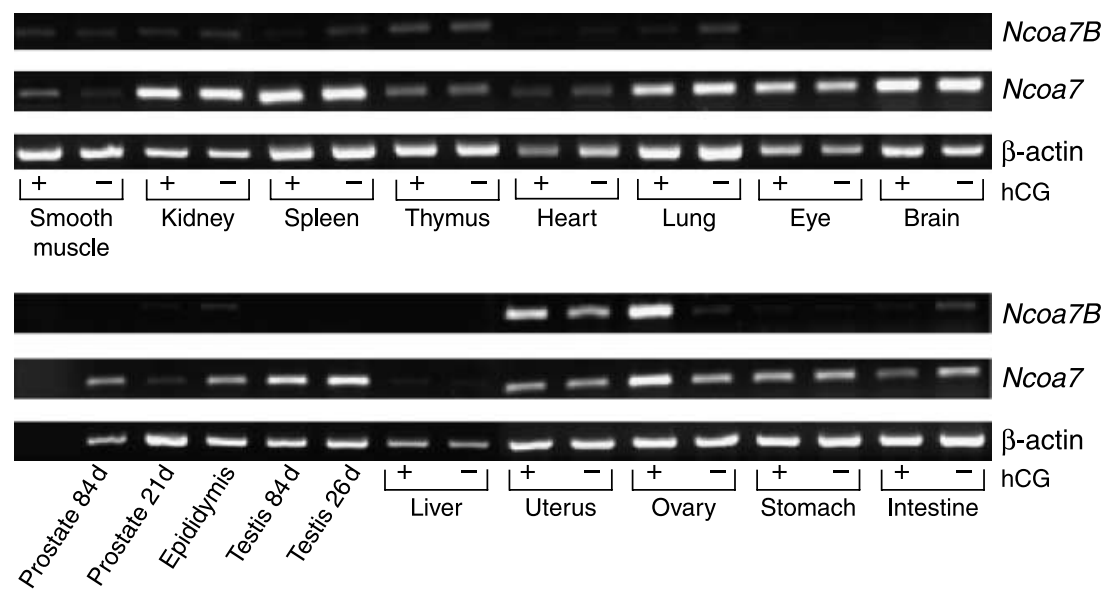

Figure 7 Tissue expression profile of Ncoa7 and Ncoa7B. Total RNA was isolated from the indicated tissues of 25-day-old immature PMSG-primed female C57BL/6 mice either treated or not treated with hCG (5 h). RNA from five additional tissues was isolated from male C57BL/6 mice. Semiquantitative RT-PCR amplification of the Ncoa7 and Ncoa7B isoforms was performed ( 35 cycles for each isoform, 24 cycles for $\beta$-actin) and the resultant PCR products were separated on a $1.5 \%$ agarose gel stained with ethidium bromide. A representative experiment is shown $(n=3)$. 
A
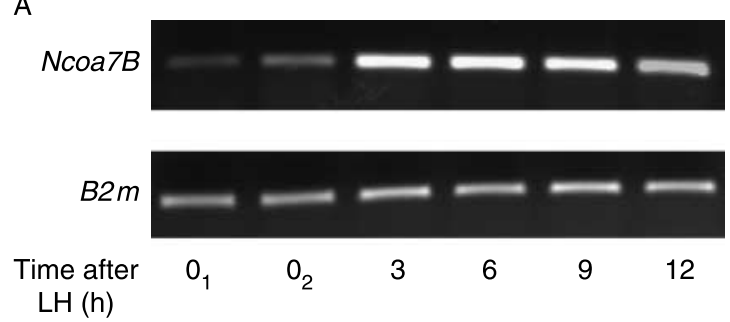

B
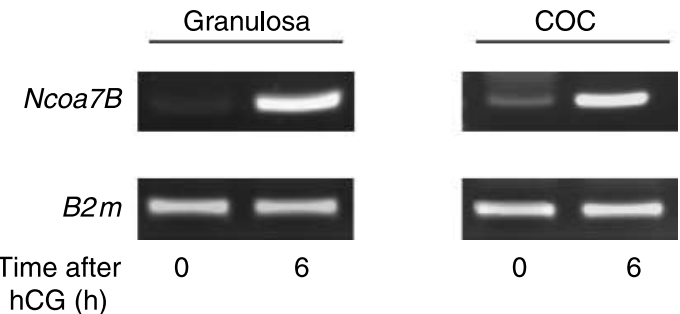
hCG (h)

Figure 8 (A) Up-regulation of Ncoa7B mRNA in murine follicles by $\mathrm{LH}$ in vitro. Autoradiograph of a representative semi-quantitative PCR analysis demonstrates $\mathrm{LH}$-dependent elevation of the $\mathrm{Ncoa} B \mathrm{~B}$ transcript in mouse preovulatory follicles. The follicles were isolated from PMSG-primed female mice and cultured in the absence $\left(0_{1}\right.$ and $0_{2}$ h samples) or the presence of $\mathrm{LH}$ for 3, 6, 9, or $12 \mathrm{~h}$. (B) Transient up-regulation of Ncoa7B mRNA in COCs and in granulosa cells of murine follicles by hCG in vivo. Autoradiograph of a representative semi-quantitative PCR analysis shows transcripts for the Ncoa7B and the $B 2 m$ genes in COCs and granulosa cells from mouse preovulatory follicles. The follicles were isolated from PMSG-primed mice, $6 \mathrm{~h}$ after hCG administration.

MAPK, whereas the other stimulates p38 kinase phosphorylation by a PKA- and PKC-independent manner. In the present study, we demonstrated that Nсоа7B mRNA expression in cultured preovulatory ovarian follicles is dependent on the $\mathrm{LH}$-induced activation of PKA, MEK, the upstream regulator of MAPK as well as p38 kinase. The partial involvement of the PKC-dependent pathway was also shown. Taken together, these experiments suggest the involvement of multiple signaling pathways in the regulation of $N$ coa $7 B$ mRNA expression, as schematically depicted in Fig. 9C.

To conclude, we have identified a novel gene that seems to have evolved through the course of vertebrate evolution and has a strong restriction to mammalian reproductive organs. Furthermore, the transient $\mathrm{LH}$ - induced expression of Ncoa7B prior to ovulation, the existence of the highly conserved TLDc domain, and the multiple-pathway regulation of this gene suggest a crucial role for $N$ coa $7 B$ in the physiology of mammalian reproduction.

\section{Materials and Methods}

\section{Animals}

Sexually immature 24-day-old female C57BL/6 mice were purchased from Harlan (Harlan Laboratories, Rehovot, Israel) and handled at the Animal Breeding Center of the Weizmann
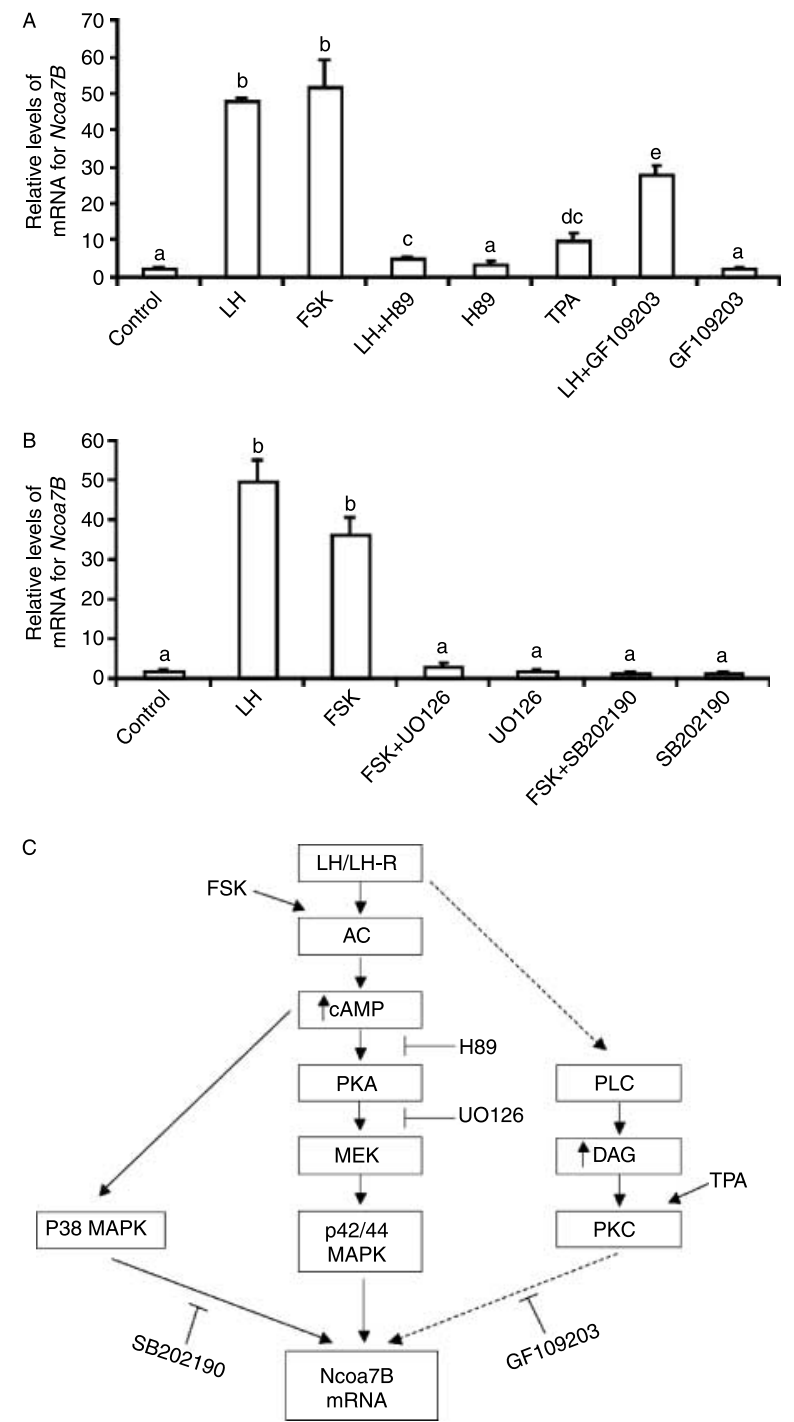

Figure 9 Regulation of Ncoa $7 B$ mRNA expression by various intracellular signaling mediators. Large antral follicles from PMSG-primed mouse ovaries cultured with or without (control) either activators or inhibitors of various intracellular signaling molecules. (A) The follicles were incubated with either LH $(1 \mu \mathrm{g} / \mathrm{ml})$, FSK $(25 \mu \mathrm{M})$, TPA $(3.5 \mu \mathrm{M})$, H89, $(25 \mu \mathrm{M})$, GF109203 $(10 \mu \mathrm{M})$, or a combination of $\mathrm{LH}$ and an inhibitor of either PKA or PKC for $6 \mathrm{~h}$. (B) The follicles were incubated with LH, FSK, UO126 $(10 \mu \mathrm{M})$, SB202190 $(20 \mu \mathrm{M})$, or with a combination of FSK and inhibitors of either MEK or p38 kinase for $6 \mathrm{~h}$. RNA $(1 \mu \mathrm{g})$ isolated from these follicles was assessed by the real-time PCR method for expression of the $N$ coa7B mRNA. The relative levels of Ncoa $7 B$ mRNA were normalized to the $B 2 m$ mRNA levels. Error bars represent the s.E.M. ( $n=3-6$ independent culture experiments; each sample of follicles included three to four C57BL/6 mice). Columns with no common superscripts are significantly different $(P<0.05)$. (C) Schematic representation of the molecular signaling pathways that control the LH-induced Ncoa7B mRNA expression. LH stimulates Ncoa7B mRNA expression via activating two independent signaling pathways: PKA and its downstream MEK as well as the p38 MAPK pathway. Even though to a much lesser extent, $\mathrm{LH}$-induced Ncoa $7 B$ mRNA can also be activated via PKC. LH-R, LH receptor; AC, adenylate cyclase; PLC, phospholipase C; DAG, diacyl glycerol. 
Institute of Science. The mice were housed in a light- (14-h light) and temperature-controlled room $\left(22{ }^{\circ} \mathrm{C} ; \quad 50-60 \%\right.$ humidity), with food and water provided ad libitum.

\section{Isolation of ovaries, COCs and granulosa cells}

All experiments were conducted in accordance with the Guide for the Care and Use of Laboratory Animals (National Research Council, National Academy of Science, Bethesda, MD, USA).

The animals were subcutaneously injected with 5 IU PMSG (Chrono-gest Intervest, Oss, The Netherlands), followed by 5 IU hCG (NV Organon, Oss, The Netherlands) intraperitoneally injected $48 \mathrm{~h}$ later. The mice were killed by cervical dislocation at different time points before and after hCG administration; the ovaries were removed and incubated in RNA Later (Ambion, Austin, TX, USA) for RNA purification from whole ovaries.

For isolation of specific ovarian cells, ovaries were removed and placed in Leibovitz's L-15 tissue culture medium, supplemented with $5 \%$ fetal bovine serum (Biological Industries, Kibbutz Beit Hemeek, Israel), penicillin (100 IU/ml), and streptomycin (100 mg/ml; Bio-Lab Ltd, Jerusalem, Israel). The ovaries were punctured by a syringe needle and either the COCs or granulosa cells were collected from the medium and immediately frozen in liquid nitrogen.

\section{Culture of follicles}

Isolated intact large antral ovarian follicles were recovered from sexually immature PMSG-primed 25-day-old female C57BL/6 mice and grown in suspension of Leibovitz's L-15 tissue culture medium containing $5 \%$ fetal bovine serum in $25 \mathrm{ml}$ flasks gassed with $50 \% \mathrm{O}_{2}+50 \% \mathrm{~N}_{2}$. Incubations were carried out at $37{ }^{\circ} \mathrm{C}$ in an oscillating water bath with or without either ovine LH (National Institutes of Health LH S-24) or forskolin (FSK, Sigma) in the presence or absence of one of the following reagents: H89 (Sigma), TPA (Sigma), GF109203 (Calbiochem, San Diego, CA, USA), UO126 (Calbiochem), or SB202190 (Calbiochem) that are inhibitors of PKA, PKC, MAPK, and p38 respectively. These inhibitors were added to the suspension $1 \mathrm{~h}$ prior to the addition of either LH or FSK to the medium. At the end of the incubation period, follicles were frozen in liquid nitrogen.

\section{RNA extraction}

Tissues and follicles were removed from the RNA Later, weighed, and homogenized in $1 \mathrm{ml}$ Tri-reagent (Sigma); COCs and granulosa cells were thawed and frozen five times in $0.5 \mathrm{ml} \mathrm{TRI}$ reagent. After the addition of $100 \mu \mathrm{l}$ chloroform and phase separation by centrifugation (30 $\left.285 \mathrm{~g}, 15^{\prime}, 4^{\circ} \mathrm{C}\right)$, the aqueous layer was washed with an equal volume of $70 \%$ ethanol and loaded onto an RNeasy minicolumn (Qiagen). The procedures for RNA isolation and purification as well as on-column Dnase treatment (Qiagen) were then carried out according to the manufacturer's instructions. The RNA samples were eluted in nuclease-free water (Qiagen). The RNA concentration was quantified (NanoDrop Technologies, Wilmington, DE, USA), and its RNA purity was assessed using 260:280 and 260:230 nm ratios. All samples had 260:280 nm ratios between 1.8 and 2.1, and $260: 230 \mathrm{~nm}$ ratios above 1.7 . The integrity of the RNA preparations was verified by the inspection of the $28 \mathrm{~S}$ and $18 \mathrm{~S}$ rRNA bands using agarose gel electrophoresis.

\section{cDNA preparation}

For each tissue, equal amounts of all RNA samples were reverse transcribed simultaneously. RNA samples (200 ng for COCs and granulosa, $1 \mu \mathrm{g}$ for follicles, and $2 \mu \mathrm{g}$ for ovaries and other tissues) were reverse transcribed using Moloney murine leukemia virus $(\mathrm{MML}-\mathrm{V})$ reverse transcriptase $\mathrm{RNase} \mathrm{H}^{+}$ (Promega Corp.) according to the manufacturer's instructions. Each reaction contained $1 \mu \mathrm{l}$ oligo(deoxythymidine) (Amersham Biosciences), $0.5 \mathrm{mM}$ of each deoxy-NTP (MBI Fermentas, St. Leon-Rot, Germany), $4 \mu$ of the $5 \times$ MML-V RT reaction buffer (Promega Corp.), $10 \mathrm{mM}$ dithiothreitol (Sigma), and $1 \mu \mathrm{l}$ of the enzyme in a total $20 \mu \mathrm{l}$ volume. All RT reactions were performed at $37^{\circ} \mathrm{C}$ and contained a negative control, which consisted of nuclease-free water instead of RNA. The cDNA was then diluted (twofold for COCs and granulosa cells, fivefold for ovarian follicles, and tenfold for ovaries and other tissues) and kept at $-20^{\circ} \mathrm{C}$.

\section{Real-time PCR}

Primers were designed using Beacon designer software (BioRad) and analyzed by the BLAT program for their specificity. Each of these primer pairs yielded only one sharp band of amplified product with the molecular weight of the desired amplicon. All primer sequences and annealing temperatures used are listed in Table 1.

All real-time PCRs were carried out on the iCycler iQ Detection System (Bio-Rad) using the DyNAmo SYBR Green qPCR Kit (Finnzymes, Oy Espoo, Finland). Reaction protocols had the following format: $15 \mathrm{~min}$ at $95^{\circ} \mathrm{C}$ for enzyme activation, followed by $40-50$ cycles of: $15 \mathrm{~s}$ at $94{ }^{\circ} \mathrm{C}, 30 \mathrm{~s}$ at the appropriate annealing temperature (see Table 1), and $30 \mathrm{~s}$ at $72{ }^{\circ} \mathrm{C}$. Fluorescence measurements of SYBR Green, an asymmetric cyanine dsDNA-specific dye, were taken at the end of the extension phase at $72{ }^{\circ} \mathrm{C}$ and also included a melt curve at the end of the cycling protocol, with continuous fluorescence measurement from 54 to $99{ }^{\circ} \mathrm{C}$. The melting curve is used to ensure product uniformity and to rule out primerdimers and splice variants. All reactions contained the same amount of cDNA, $10 \mu \mathrm{l}$ DyNAmo SYBR Green qPCR Mix, 10 pmol of each primer, and UltraPure PCR-grade water (Sigma) to a final $20 \mu \mathrm{l}$ volume.

Each real-time PCR included a no-template control as well as four or five serial fourfold dilutions, in triplicate, of a cDNA pool containing all experimental samples of the respective tissue. The pre-normalized DNA quantity of each gene in every sample was estimated relative to this dilution series. This dilution series also served to assess the reaction performance (E and $\left.r^{2}\right)$.

The PCR was normalized against $B 2 m$, the expression of which did not vary across the experimental conditions. Optical data obtained by real-time PCR were analyzed using the default and variable parameters available in the iCycler iQ Optical system Software (Version 3.0a, Bio-Rad). 
Table 1 Primer sequences and optimized annealing temperatures.

\begin{tabular}{|c|c|c|}
\hline \multirow{3}{*}{$\begin{array}{l}\text { Gene (accession number) } \\
5 \mathrm{~B} 6\end{array}$} & Primer sequence $\left(5^{\prime}-3^{\prime}\right)$ & \multirow{2}{*}{$\begin{array}{l}\text { Annealing temperature }\left({ }^{\circ} \mathrm{C}\right) \\
58\end{array}$} \\
\hline & AACCACCATCCACGGCTGTC & \\
\hline & Antisense: CTCTTCGGAGGATTCCACAGGC & \\
\hline $6 \mathrm{C} 3$ for $5^{\prime} \mathrm{RACE}$ & GGTCAGGCCTGGCACAATAGAAAA & 68 \\
\hline $6 \mathrm{C} 3$ for $3^{\prime} \mathrm{RACE}$ & CAGGCAACCAGAGAAAGACCGATT & 68 \\
\hline \multirow{2}{*}{ 6C3/Ncoa7B(EF602028) } & GTCTTCTGTCCCAGCACCATGAG & 60 \\
\hline & Antisense: СССТСТТССТСТТСТТССТСТТСС & \\
\hline \multirow[t]{2}{*}{ 4E4 } & Sense: GCCCAGAAGCGGGGTAAATTCC & 58 \\
\hline & Antisense: GATGGCAGCGGTCTCTGTGTTC & \\
\hline \multirow[t]{2}{*}{$2 \mathrm{~F} 12$} & CATTTGTAGACCGTCCTTTCACTG & 58 \\
\hline & Antisense: TGTGTCGGGCTCAGCAGATG & \\
\hline \multirow[t]{2}{*}{$3 \mathrm{~F} 1$} & Sense: GTACCAAACAAACGGCATCCAG & 58 \\
\hline & Antisense: CATATCCTTGTCTGACAACTCACC & \\
\hline \multirow{2}{*}{$2 \mathrm{G} 12$} & Sense: $\quad$ GATGCTACCGTGCCCACTCTG & 58 \\
\hline & Antisense: AGACAGCCCGTAGAGGAGAGC & \\
\hline \multirow{2}{*}{ Ncoa7 (NM_172495) } & Sense: $\quad$ TGATTAAAGAGGACGTTTCCAA & 60 \\
\hline & Antisense: CTGCССТССАСАGTACСТTC & \\
\hline \multirow[t]{2}{*}{$\beta$-actin (NM_007393) } & Sense: $\quad$ CCCCATTGAACATGGCATTGTTAC & 56 \\
\hline & Antisense: TTGATGTCACGCACGATTTCC & \\
\hline \multirow[t]{2}{*}{ B2m (NM_009735) } & Sense: $\quad$ CCCGCCTCACATTGAAATCC & 58 \\
\hline & Antisense: GCGTATGTATCAGTCTCAGTGG & \\
\hline
\end{tabular}

\section{Semi-quantitative RT-PCR}

Semi-quantitative RT-PCR was performed to examine the relative expression levels of the Ncoa7B mRNA in the follicles, COCs, and granulosa cells. B2m was used for the normalization of mRNA levels between different samples. To establish the optimal number of PCR cycles falling in the linear range of amplification (exponential amplification), we tested the range between 24 and 36 cycles (every three cycles) for each type of cDNA sample, both for $N_{\text {COa }} B$ and $B 2 m$ amplifications. The response of $N$ coa $B B$ was in the linear range at 28,30, and 31 cycles in the follicles, COCs, and granulosa respectively and at 24 cycles for $B 2 \mathrm{~m}$.

All PCRs were performed in $25 \mu \mathrm{l}$ reaction volumes containing $2 \mu \mathrm{l}$ cDNA, 5 pmol of each primer, and $25 \mu \mathrm{l}$ ReddyMix PCR Master Mix (ABgene, Epsom, UK), yielding a final concentration of $1.5 \mathrm{mM} \mathrm{MgCl}$. The PCR cycling conditions included a $94{ }^{\circ} \mathrm{C}$ heating step for 2 min at the initiation of every run. Samples were amplified for a specific number of cycles, with the following cycle profile: $30 \mathrm{~s}$ at $94{ }^{\circ} \mathrm{C}, 30 \mathrm{~s}$ at the designated annealing temperature and $30 \mathrm{~s}$ at $72{ }^{\circ} \mathrm{C}$. This was followed by a 3-min final incubation at $72{ }^{\circ} \mathrm{C}$. The PCR products were separated by electrophoresis on $2 \%$ agarose gels containing ethidium bromide and photographed under u.v. illumination.

\section{Multiple tissue array}

From two immature PMSG/hCG-treated and two untreated female mice, 13 different tissues were isolated. Five additional tissues were isolated from two sexually mature and two immature male C57BL/6 mice. Animals were perfused with cold PBS solution (Invitrogen Life Technologies) prior to tissue dissection. PCR amplification of the isoforms, using the abovedescribed protocol, was performed following RNA extraction and cDNA preparation. For tissue distribution analysis of the Ncoa7 and Ncoa7B isoforms, 35 PCR cycles were performed. $\beta$-actin was used as a reference gene.

\section{Full-length cDNA sequence determination}

The $5^{\prime}$ and $3^{\prime}$ ends of the 6C3 (Ncoa7B) cDNA were determined by the SMART RACE cDNA Amplification Kit (Clontech), according to the manufacturer's instructions. This technology provides a mechanism for generating full-length cDNAs in RT reactions (Zhu et al. 2001). Briefly, $1 \mu \mathrm{g}$ total ovarian RNA was converted into cDNA with PowerScript RT (Clontech) at $42{ }^{\circ} \mathrm{C}$ for $1.5 \mathrm{~h}$. A $5^{\prime}$-RACE-Ready cDNA was obtained with the $5^{\prime}$-CDS primer, for first-strand synthesis, and the SMART II A oligonucleotides from the kit; 3'-RACE-Ready cDNA was obtained with the $3^{\prime}$-CDS primer. First-strand synthesis was primed using a modified oligo (dT) primer. SMART II A oligonucleotide served as an extended template for PowerScript RT. The $5^{\prime}$ and $3^{\prime}$ RACE reactions were conducted with the Universal Primer Mix A from the kit and gene-specific primers (GSPs), carefully designed according to the manufacturer's instructions. Thirty five cycles were carried out with $30 \mathrm{~s}$ denaturation at $94{ }^{\circ} \mathrm{C}, 30 \mathrm{~s}$ annealing at $68^{\circ} \mathrm{C}$, and $3 \mathrm{~min}$ extension at $72{ }^{\circ} \mathrm{C}$.

The $5^{\prime}$ and $3^{\prime}$ PCR products were purified by using Nucleo Trap Gel Extraction kit (Clontech) and ligated into the pGEM$\mathrm{T}$ vector (Promega) according to the manufacturer's protocol. The vector was then transformed into $\mathrm{DH} 5 \alpha$ ECOS 1-min competent cells (RBC Bioscience, Chungho City, Taipei County, Taiwan), which contain a chromosomal isopropyl $\beta$-D-1-thiogalactopyranoside (IPTG)-inducible $\beta$-galactosidase gene. On LB plates, $50 \mu \mathrm{l}$ of $50 \mathrm{mg} / \mathrm{ml} \mathrm{X-Gal} \mathrm{(Promega)} \mathrm{and}$ $150 \mu \mathrm{l}$ of $23.8 \mathrm{mg} / \mathrm{ml}$ IPTG (Sigma) were carefully overlaid, and the transformed bacteria were selected out by ampicillin resistance and $\beta$-gal inactivity. Positive colonies were picked and grown overnight on LB plates containing $50 \mu \mathrm{g} / \mathrm{ml}$ ampicillin at $37^{\circ} \mathrm{C}$, and the plasmids were purified using the QIAprep Spin Plasmid kit (Qiagen). Automated sequencing was conducted using the $\mathrm{ABI} 3700$ DNA Analyzer (Applied Biosystems, Foster City, CA, USA). Identical nucleotide sequence corresponding to the $5^{\prime}$ end as well as to the $3^{\prime}$ end of 6C3 (Ncoa7B) cDNA was obtained by 
sequence analysis of three to six independent clones. The sequence was deposited in GenBank and was assigned the accession number EF602028.

\section{Bioinformatics analyses}

SSH library fragments were analyzed using multiple bioinformatics tools: BLAST (NCBI, http://www.ncbi.nlm.nih.gov/ BLAST/), BLAT (UCSC genome browser, http://genome.ucsc. edu), Mouse Genome Informatics (http://www.informatics.jax. org/), and domain databases (InterPro, http://www.ebi.ac.uk/ interpro/). The RACE products were analyzed by BLAST and BLAT. Related sequences were isolated by protein BLAST, and culled to exclude predicted proteins, protein fragments, and redundancies. Additional sequences were identified by the translation of mRNAs found in the 'other mRNAs' track in the UCSC genome browser. When possible, sequences were built from ESTs found in the EST tracks of the UCSC genome browser. Alignments were performed using ClustalW version 1.83 (Thompson et al. 1994), and visualized using Prettybox from the GCG package (Wisconsin Package Version 10.3, Accelrys Inc., San Diego, CA, USA). Phylogenetic trees were built using the Phylip package version 3.65 (Proml - maximum likelihood). The trees were visualized using TreeDyn (http:// www.treedyn.org; Chevenet et al. 2006).

\section{Statistical analyses}

The number of repetitions for each individual experiment is indicated in the relevant figure legend. All data are presented as means \pm S.E.M. Statistical significance was determined by the parametric multiple comparison test, ANOVA, to assess the differences between multiple experimental groups. The experiments examining the effect of different activators and inhibitors on $N$ соа $7 B$ mRNA expression were analyzed by paired Student's $t$-tests, with a $P$ value of $<0.05$ considered significant.

\section{Acknowledgements}

The authors would like to thank Dr N Nevo for animal handling for the tissue array assay, Irit Orr for advice on the phylogenetic studies and critical reading of the manuscript, and Yitzhak Reizel for providing RNA of COCs and granulosa cells and for critical review of this manuscript. This study was supported in part by grants from the Center for Women's Health Research, WIS; Chief Scientist Office, Israel ministry of Health; the Israel Science foundation (682/04); and the Dwek Fund for Biomedical Research. N Dekel is the incumbent of the Philip M Klutznick Professional Chair in Developmental Biology. The authors declare that there is no conflict of interest that would prejudice the impartiality of this scientific work.

\section{References}

Adashi EY 1990 The potential relevance of cytokines to ovarian physiology: the emerging role of resident ovarian cells of the white blood cell series. Endocrine Reviews 11 454-464.
Brannstrom M, Mayrhofer G \& Robertson SA 1993 Localization of leukocyte subsets in the rat ovary during the periovulatory period. Biology of Reproduction 48 277-286.

Carvalho CR, Carvalheira JB, Lima MH, Zimmerman SF, Caperuto LC, Amanso A, Gasparetti AL, Meneghetti V, Zimmerman LF, Velloso LA et al. 2003 Novel signal transduction pathway for luteinizing hormone and its interaction with insulin: activation of Janus kinase/signal transducer and activator of transcription and phosphoinositol 3-kinase/Akt pathways. Endocrinology 144 638-647.

Chevenet F, Brun C, Banuls AL, Jacq B \& Christen R 2006 TreeDyn: towards dynamic graphics and annotations for analyses of trees. BMC Bioinformatics 7439.

Croteau DL \& Bohr VA 1997 Repair of oxidative damage to nuclear and mitochondrial DNA in mammalian cells. Journal of Biological Chemistry 272 25409-25412.

Diatchenko L, Lau YF, Campbell AP, Chenchik A, Moqadam F, Huang B, Lukyanov S, Lukyanov K, Gurskaya N, Sverdlov ED et al. 1996 Suppression subtractive hybridization: a method for generating differentially regulated or tissue-specific cDNA probes and libraries. PNAS 93 6025-6030.

Durand M, Kolpak A, Farrell T, Elliott NA, Shao W, Brown M \& Volkert MR 2007 The OXR domain defines a conserved family of eukaryotic oxidation resistance proteins. BMC Cell Biology 813.

Elliott NA \& Volkert MR 2004 Stress induction and mitochondrial localization of Oxr1 proteins in yeast and humans. Molecular and Cellular Biology 24 3180-3187.

Eppig JJ 1991 Maintenance of meiotic arrest and the induction of oocyte maturation in mouse oocyte-granulosa cell complexes developed in vitro from preantral follicles. Biology of Reproduction 45 824-830.

Espey LL 1980 Ovulation as an inflammatory reaction - a hypothesis. Biology of Reproduction 22 73-106.

Espey LL 1994 Current status of the hypothesis that mammalian ovulation is comparable to an inflammatory reaction. Biology of Reproduction $\mathbf{5 0}$ 233-238.

Espey LL \& Richards JS 2002 Temporal and spatial patterns of ovarian gene transcription following an ovulatory dose of gonadotropin in the rat. Biology of Reproduction 67 1662-1670.

Espey LL, Ujioka T, Russell DL, Skelsey M, Vladu B, Robker RL, Okamura H \& Richards JS 2000 Induction of early growth response protein-1 gene expression in the rat ovary in response to an ovulatory dose of human chorionic gonadotropin. Endocrinology 141 2385-2391.

Fischer H, Zhang XU, O'Brien KP, Kylsten P \& Engvall E 2001 C7, a novel nucleolar protein, is the mouse homologue of the Drosophila late puff product L82 and an isoform of human OXR1. Biochemical and Biophysical Research Communications 281 795-803.

Gershon E, Hourvitz A, Reikhav S, Maman E \& Dekel N 2007 Low expression of COX-2, reduced cumulus expansion, and impaired ovulation in SULT1E1-deficient mice. FASEB Journal 21 1893-1903.

Hourvitz A, Gershon E, Hennebold JD, Elizur S, Maman E, Brendle C, Adashi EY \& Dekel N 2006 Ovulation-selective genes: the generation and characterization of an ovulatory-selective cDNA library. Journal of Endocrinology 188 531-548.

Hsieh M \& Conti M 2005 G-protein-coupled receptor signaling and the EGF network in endocrine systems. Trends in Endocrinology and Metabolism $16320-326$.

Hsu SY \& Hsueh AJ 2000 Discovering new hormones, receptors, and signaling mediators in the genomic era. Molecular Endocrinology 14 594-604.

Jo M, Gieske MC, Payne CE, Wheeler-Price SE, Gieske JB, Ignatius IV, Curry TE Jr \& Ko C 2004 Development and application of a rat ovarian gene expression database. Endocrinology 145 5384-5396.

Ko C, Gieske MC, Al-Alem L, Hahn Y, Su W, Gong MC, Iglarz M \& Koo Y 2006 Endothelin-2 in ovarian follicle rupture. Endocrinology $\mathbf{1 4 7}$ 1770-1779.

Leo CP, Vitt UA \& Hsueh AJ 2000 The ovarian kaleidoscope database: an online resource for the ovarian research community. Endocrinology 141 3052-3054.

Leo CP, Pisarska MD \& Hsueh AJ 2001 DNA array analysis of changes in preovulatory gene expression in the rat ovary. Biology of Reproduction 65 269-276.

Loft S \& Poulsen HE 1996 Cancer risk and oxidative DNA damage in man. Journal of Molecular Medicine 74 297-312. 
Marnett LJ 2000 Oxyradicals and DNA damage. Carcinogenesis 21 361-370.

Morris JK \& Richards JS 1995 Luteinizing hormone induces prostaglandin endoperoxide synthase- 2 and luteinization in vitro by A-kinase and C-kinase pathways. Endocrinology 136 1549-1558.

Murdoch WJ 2005 Carcinogenic potential of ovulatory genotoxicity. Biology of Reproduction 73 586-590.

Nakamura Y, Smith M, Krishna A \& Terranova PF 1987 Increased number of mast cells in the dominant follicle of the cow: relationships among luteal, stromal, and hilar regions. Biology of Reproduction 37 546-549.

Natraj U \& Richards JS 1993 Hormonal regulation, localization, and functional activity of the progesterone receptor in granulosa cells of rat preovulatory follicles. Endocrinology 133 761-769.

Park OK \& Mayo KE 1991 Transient expression of progesterone receptor messenger RNA in ovarian granulosa cells after the preovulatory luteinizing hormone surge. Molecular Endocrinology 5 967-978.

Park HJ, Lee J, Wang L, Park JH, Kwon HB, Arimura A \& Chun SY 2000 Stage-specific expression of pituitary adenylate cyclase-activating polypeptide type I receptor messenger ribonucleic acid during ovarian follicle development in the rat. Endocrinology 141 702-709.

Park JY, Su YQ, Ariga M, Law E, Jin SL \& Conti M 2004 EGF-like growth factors as mediators of $\mathbf{L H}$ action in the ovulatory follicle. Science $\mathbf{3 0 3}$ 682-684.

Ramotar D, Popoff SC, Gralla EB \& Demple B 1991 Cellular role of yeast Apn1 apurinic endonuclease/3'-diesterase: repair of oxidative and alkylation DNA damage and control of spontaneous mutation. Molecular and Cellular Biology 11 4537-4544.

Richards JS 1979 Hormonal control of ovarian follicular development: a 1978 perspective. Recent Progress in Hormone Research 35 343-373.

Richards JS 1994 Hormonal control of gene expression in the ovary. Endocrine Reviews 15 725-751.

Richards JS 2005 Ovulation: new factors that prepare the oocyte for fertilization. Molecular and Cellular Endocrinology 234 75-79.

Richards JS, Russell DL, Ochsner S \& Espey LL 2002a Ovulation: new dimensions and new regulators of the inflammatory-like response. Annual Review of Physiology 64 69-92.

Richards JS, Russell DL, Ochsner S, Hsieh M, Doyle KH, Falender AE, Lo YK \& Sharma SC $2002 b$ Novel signaling pathways that control ovarian follicular development, ovulation, and luteinization. Recent Progress in Hormone Research 57 195-220.
Robker RL \& Richards JS 1998 Hormone-induced proliferation and differentiation of granulosa cells: a coordinated balance of the cell cycle regulators cyclin D2 and p27Kip1. Molecular Endocrinology 12 924-940.

Salvador LM, Maizels E, Hales DB, Miyamoto E, Yamamoto H \& Hunzicker-Dunn M 2002 Acute signaling by the LH receptor is independent of protein kinase $C$ activation. Endocrinology 143 2986-2994.

Shao W, Halachmi S \& Brown M 2002 ERAP140, a conserved tissuespecific nuclear receptor coactivator. Molecular and Cellular Biology 22 3358-3372.

Sharma SC, Clemens JW, Pisarska MD \& Richards JS 1999 Expression and function of estrogen receptor subtypes in granulosa cells: regulation by estradiol and forskolin. Endocrinology 140 4320-4334.

Sirois J \& Richards JS 1992 Purification and characterization of a novel, distinct isoform of prostaglandin endoperoxide synthase induced by human chorionic gonadotropin in granulosa cells of rat preovulatory follicles. Journal of Biological Chemistry 267 6382-6388.

Sirois J \& Richards JS 1993 Transcriptional regulation of the rat prostaglandin endoperoxide synthase 2 gene in granulosa cells. Evidence for the role of a cis-acting C/EBP beta promoter element. Journal of Biological Chemistry 268 21931-21938.

Thompson JD, Higgins DG \& Gibson TJ 1994 CLUSTAL W: improving the sensitivity of progressive multiple sequence alignment through sequence weighting, position-specific gap penalties and weight matrix choice. Nucleic Acids Research 22 4673-4680.

Tullet JM, Pocock V, Steel JH, White R, Milligan S \& Parker MG 2005 Multiple signaling defects in the absence of RIP140 impair both cumulus expansion and follicle rupture. Endocrinology 146 4127-4137.

Volkert MR, Elliott NA \& Housman DE 2000 Functional genomics reveals a family of eukaryotic oxidation protection genes. PNAS 97 14530-14535.

Zhu YY, Machleder EM, Chenchik A, Li R \& Siebert PD 2001 Reverse transcriptase template switching: a SMART approach for full-length cDNA library construction. BioTechniques 30 892-897.

Received 5 September 2007

First decision 17 October 2007

Accepted 4 December 2007 